\title{
Thinking skills and creativity in second language education: where are we now?
}

\author{
Li Li University of Exeter \\ Graduate School of Education \\ College of Social Sciences \& International Studies \\ University of Exeter
}

Heavitree Road, EX1 2LU

li.li@exeter.ac.uk

\section{Introduction}

In recent years, there has been a surge in interest in ways of developing thinking and learning skills for learners (Wegerif, Li and Kaufman, 2015), and this interest has been extensively reflected in educational policies, curriculum design and teaching practice across the world ( $L i$, this issue). The underlying assumption of focusing on developing learners' thinking skills is that these skills are crucial in developing new knowledge and collaboration. On the one hand, increasing globalisation requires more people to be equipped with 21st century skills, which in turn requires schools to be able to restructure education to include much greater focus on developing critical and creative skills. On the other hand, interest in teaching thinking has been highly influenced by the development of digital and networked technologies (Wegerif, 2006) and the emergence of '21st century skills' (Voogt et al., 2013). 21st century skills include being creative and able to argue for a position or course of action, and able to concede to stronger arguments and evidence. When we compare what constitutes 'learning' and 'knowledge' between now and 20 years ago, we can easily come to the conclusion that it is more difficult to define what 'knowing' means today. There are two factors contributing to the difficulties: first, new technological tools and digital data have changed the nature of knowledge for the next generation of learners, whilst it has certainly changed the nature of information in terms of its representation, translation and access, the nature of knowing is more problematic (Higgins, 2014). Second, since the nature of knowledge has changed, the digital world requires a different emphasis in the school curriculum, particularly in terms of developing a critical understanding of the nature of information and its value to help answer particular questions or solve particular problems: information processing and evaluation.

The particular ways in which people apply their minds to solving problems are called thinking skills. This issue posits that developing thinking skills is important for second language learning. On the one hand, second language acquisition research and teaching has recognised that learners take primary responsibility in acquiring a second language, whereas teachers play the role of facilitating this acquisition to happen. The primary responsibility that learners take in learning a second language requires learners not to simply remember and recall language in its abstract form, but to engage in critical and creative analysis and evaluation of material at hand in order to internalise the language. On the other hand, however, limited progress has been made in addressing developing learners' higher order thinking skills in second language education (e.g. Li, 2011). Similarly, little progress has been made in answering some of the most pertinent questions that matter to second language acquisition: 
what exactly (higher order) thinking skills do second language learners need to acquire in order to regulate and facilitate their learning? How do language teachers create an environment or space to develop learners' good thinking skills when they teach a foreign language? Are there any tools that we can utilise to develop learners' thinking skills? To me, these questions constitute the central point of the current project: enabling readers to consider different theoretical, methodological and practical aspects of researching and teaching thinking skills.

In second language education, research suggests that cognition and language development are closely related and this is widely recognized by theorists and educators. In particular, developing thinking skills may promote higher levels of language proficiency and really learning a language implies learning to think in the target language. In recent years, thinking skills have been explored in various ways, such as metacognition in L2 reading and writing, critical and creative thinking in L2 classrooms, self-regulation of second language learners, and developing a thinking skill based curriculum. Despite the importance of teaching thinking skills, integrating thinking in language teaching has been peripheral and this special issue aims to present a comprehensive collection of innovative papers that will highlight the current research in this area and raise questions that will set the direction for future research. The practice of teaching thinking takes many forms, and in second language research critical thinking and metacognition have been dominant areas of inquiry.

\section{Critical thinking}

Teaching thinking is important for learning and social practice to develop global citizens with creativity and innovative capacity (MacDonald, 2005). Some people might find that the term 'teaching thinking' sounds a little vague. They might prefer something that sounds more precise like 'cognitive skills' or 'Higher Order Thinking' or 'critical thinking'. Critical thinking has been the most widely researched concept in education (Fisher, 2011). However, it is also a fuzzy term which is difficult to define and describe. For example, Dewey (1909) defined it as active, persistent, and careful consideration of a belief or supposed form of knowledge in the light of the grounds which support it and the further conclusions to which it tends (p.9) In second language education, Atkinson (1997) defined critical thinking as a "social practice" (p. 72) and concluded that "critical thinking is cultural thinking" (p. 89). Other researchers consider it as "healthy skepticism" (Lipman, 2003), or an ability to engage in reflective thinking in relation to the context (Li \& Wegerif, 2014). Other definitions of critical thinking include 'a cognitive activity, associated with using the mind' (Cottrell, 2005, p.1), and 'skilled and active interpretation and evaluation of observations and communications, information and argumentation' (Fisher and Scriven, 1997, p.21).

Despite the various understandings of the term, researchers and educators all agree that criticality is important in learning. For example, the ability to recognize, construct, and evaluate arguments, and the skills of analysing, synthesizing and critiquing material are essentially the foundation of academic success in higher education. Much research in thinking skills in second language education therefore focuses on developing critical thinking through reading and writing. There is strong evidence that CTintegrated instruction improved student achievement. Research suggests positive outcome in speaking and listening through integrating thinking skills in teaching (e.g. Yang et al., 2013; Yang, 2012), in both oral and written performances (Wu, Marek \& Chen, 2013); online reading course and forum have positive impact on students' thinking and academic writing skills (Wang \& Henderson, 2014). Thus, a close relationship between language proficiency level and critical thinking can be established (DeWaelsche, 2015) and researchers strongly suggest that critical thinking needs to be explicitly taught 
(Wu, Marek, Chen, 2013; Marin and Halpern 2011). For this reason, various approaches are proposed to foster critical thinking, such as integrating critical thinking in CLIL (Lockley, 2013) and integrating critical thinking in academic curriculum design.

Two areas are worth noting in promoting critical thinking. First, questioning techniques, interactional structures and teacher feedback can promote or hinder thinking space (Li, 2011) and this space needs to be consciously created and developed; second, the quality of critical thought depends on the topic content, with a familiar topic generating better CT (Stapleton, 2001). Therefore, in order to facilitate good thinking, topics need to be relevant to students both at cognitive and affective levels. There seems to be an urgent need to integrate thinking skills (e.g. CT) in foreign language teaching as EFL learners demonstrate low level of CT in reading and writing (Zhou, Jiang \& Yao, 2014)

\section{Metacognition}

Metacognition, first coined by Flavell (1979), refers to "knowledge concerning ones' own cognitive processes and products or anything related to them" which includes "the active monitoring and consequent regulation and orchestration of these processes in relation to the cognitive objects or data on which they bear, usually in the service of some concrete goal or objective" (p.232). Simply put, the concept of metacognition includes one's knowledge of cognitive resources (knowledge) and their regulation (control). Raising students' metacognitive awareness and knowledge is an important agenda in the field of second language acquisition. Much research has been carried out in reading and writing to understand learners' online decision making in regulating their actions, self-control mechanisms, and strategies they use in monitoring, regulating, and controlling text comprehension.

The major focus of metacognitive research should still remain in identifying students' metacogntive strategy use in relation to their proficiency levels in L2, especially in reading as research in this area is still cursory (Zhang, 2010). In researching metacognition, various research methodologieshave been adopted, including a combination of interview and think-aloud and journals (Li \& Munby, 1996), survey (Sheory and Mokhtari, 2001; Mo'nos, 2005), comparison of tests between groups with different treatment (Kletzien, 1991). Clearly, relying solely on a single method of data collection weakens and questions the internal validity/credibility of the findings derived. So in order to gain insights into what, how, when, and why the strategy is used, multiple methods should be considered for a single research study, such as retrospective interviews, observation, learning journals, and think-aloud techniques, survey and eye-tracking devices. Liu \& Li (2015) reviewed studies in metacognitive knowledge and strategies in second language learning, and proposed a useful suggestion on the use of think-aloud protocol.

Another area of metacognition research is the discussion on the relationship between metacognition and academic success. There is also evidence that successful learners use different metacognitive strategies from less successful learners (Yayli, 2010). For example, successful L2 learners were reported to use a variety of idiosyncratic metacognitive strategies including,

- Translation: using their L1 as a base for understanding or producing the $\mathrm{L} 2$.

- Use of background knowledge: using personal and general knowledge to associate with the text being read.

- Self-questioning: questioning oneself while reading to check understanding. 
- Guessing unknown words or phrases and predicting text content: using contextual clues to predict and guess and skip unknown words that were not considered essential to overall comprehension.

- Paying attention to topic sentences: providing the 'gist' of the paragraph being read.

- Picking out key words: paying attention to the words that are important to connect them together into the 'chunk' of information for better understanding.

- Comparison and contrast to the L1 knowledge domain: readers seeing the differences and similarities between their L1 and L2 knowledge in order not to misunderstand the context.

Concerning EFL learners in Taiwan, Zhang (2001) pointed out the strategies that good readers might use, including (1) anticipating text contexts, (2) monitoring comprehension, (3) stating a lack of background or schema knowledge, (4) skimming for main ideas, (5) guessing the meaning from the context through inferences, and (6) asking for help for clarification. By contrast, the strategies that the low-scorers employed frequently included: (1) translating into L1, (2) acknowledge a lack of lexical resources, and (3) using dictionaries more frequently. His later research (Zhang 2010) suggests that there is a strong relationship between metacognition and successful EFL reading comprehension, and that the successful and the less successful L2 students are different in the amount and the quality of the metacognitive knowledge they possess. Understanding successful learners' metacognitive knowledge and strategies has a strong implication on pedagogical improvement as teachers might be able to train students to use particular metacognitive strategies to monitor, control and regulate their learning.

\section{This issue}

This special issue consists of this introduction and, four research individual papers and two commentaries. The papers which make up this issue exemplify the centrality of thinking skills and creativity to learning, and highlight the many different ways in which these key concepts can be investigated. By adopting different perspectives to the study of creativity and thinking skills, the papers presented here further our understanding of complex phenomena such as the role of technology in creativity-led teaching developing thinking skills; the attitudes of teachers and their conceptions of thinking skills; the importance of integrating thinking skills in academic disciplines.

This volume addresses a number ofphenomena, all related in some way to the central understanding of teaching, learning, teachers and assessment, and the role of thinking skills in developing second language proficiency. It is important to point out here that this introduction, along with the contributions to the special issue, do not claim a comprehensive treatment of this complex concept. What it does do, however, is to highlight potential issues concerning second language educators in developing cognitively sophisticated and socially engaging learners, and to open up a space for more discussion in integrating thinking skills in second language learning.

Two papers in this special issue tackles critical thinking in second language instruction. Lin, Prestona, Kharrufab and Kong (this volume) explored the use of Computer Supported Collaborative Learning Environments(CSCLE) as multimodal spaces for promoting critical thinking for English as a second language from multiple perspectives, namely technology, thinking skills and Interaction. The use of a 
multitouch tabletop and an accompanying application Digital Mysteries proved to be useful for making reasoning skill visible for $L 2$ learning in Higher Education. What this paper certainly highlights is one potential area for future exploration, which is how we embrace the affordances of technology not to develop thinking skills for learners, but also make the 'thinking moment' visible and analysable for research purposes. By tracking critical reasoning, for example, we will be able to not only identify what critical reasoning is like, but also make a link between reasoning and knowledge development and creation. The other paper by Wilson (this volume) also investigate critical thinking in a tertiary education context, with a specific focus on university preparation courses. As argued earlier, critical thinking is also the key to academic success, and this paper further fostered this position by arguing that developing the ability to read - and to read critically - is vital for aspiring university students. Recognising the weakness of general EAP courses in promoting critical thinking, Wilson reports on the findings of an ethnographic study of three EAP teaching-learning contexts in Australia and relates the pedagogy of these classrooms to theories of critical thinking identified by Davies and Barnett (2015). This paper suggests that critical reading pedagogy can be realised in different ways, but that nurturing students' critical dispositions, in particular, requires delicate scaffolding to support their development as critical meaning-makers. Such scaffolding pushes students to develop deeper skills and criticality, yet enables them to feel secure in the transcultural contact zones in which they are participating. Scaffolding, indeed, is a very important tool to facilitate critical thinking or any good thinking skills. As Vygostky (1978) argued that there was a close link between language and thought.

Taking writing as an example, Teng examined the effectiveness of cooperative training strategies in enhancing students' metacognitive skills and therefore their English writing, as writing involves both cognitive and metacognitive processes. A total of 120 Chinese university students were divided equally into three groups that were learning writing under distinct circumstances-a cooperative learning condition with embedded metacognitive instructions (COOP + META), a cooperative learning condition (COOP), and a non-treatment control group. Results indicated that the COOP + META condition yielded the highest mean scores in writing and regulation of cognition, followed by the COOP condition and the control group. Teng's study strongly suggested that students' writing has improved due to the treatment, but no significant improvement was noticed in the knowledge about cognition for the IMPROVE students although they exhibited different kinds of cognitive regulation processes.

Given the significant importance of thinking skills to social practice and learning, it is not difficult to imagine why teachers across the world are encouraged to integrate thinking skills in teaching. However, as Li (this volume) rightly pointed out that little is known about teachers' conceptions, beliefs and practice about integrating thinking skills in foreign language instruction. Li's paper addresses this issue by examining teachers' cognition about thinking skills in EFL classrooms in China through the analysis of 473 self-completed questionnaires, four focus group interviews with 18 teachers and a further follow-up classroom observation and video-based reflection of three teachers. This study suggests that EFL teachers in China find it difficult to define thinking skills and hold fragmented and insufficient understanding about the concept. Although the participating teachers demonstrated overall positive attitudes towards integrating thinking skill, they do not believe thinking skills have a strong link with language instruction. She also identified some influential factors contributing to teachers' integration of thinking skills in teaching, including the focus of the English subject, curriculum, class time and textbooks. There is a strong case for arguing for immediate teacher training to develop both content and pedagogical knowledge of teaching thinking skills. More importantly, teachers need to understand the central role of thinking in learning a language (Mok, 2009; Lockley, 2013). 


\section{Future research and conclusion}

The articles in this special issue make a case for promoting good thinking skills in second language education, and raise a few questions about how we can facilitate thinking in subject learning. This issue also identifies new directions for researching and teaching thinking skills.

A first new direction, is a focus on creative thinking or 'possibility thinking' (Craft, 2000). One of the reasons is that creative thinking is by and large perceived as non-academic and less serious compared to critical thinking, thus, very little effort is made in promoting creative thinking in language learning. This misconception does not only exist in second language education, in fact, it is a widely spread issue among teachers as creativity might distract learners from engaging with academic 'truths' (e.g. Li, this volume, Beghetto 2008). A second possible reason is that creative thinking is a relatively new concept, which is hard to define. We understand creativity can be defined as big C and little C (Craft, 2005). However, it is very often the big ' $C$ ' that people are more familiar with, which is eminent creativity. The goals are often to study the creative greatness. Little ' $C$ ' is defined as everyday creativity, which concerns creative activities that one might engage in everyday life, for example, learning English, in successfully identifying and navigating the matter at hand (Craft, 2001). The little ' $C$ ' highlights the value and nature of personal agency in relation to both finding and solving problems, using intuition as well as logic to cope with everyday challenges, and as inherently innovative, enabling forward motion in all aspects of life (Kaufman \& Beghetto, 2009). However, in practice, little ' $C$ ' is more difficult to pin down and for teachers to engage in teaching for creativity. Kaufman (2009) also highlights the mini ' $C$ ', arguing the personal (Runco, 1996; Vygotsky, 1967/2004) and developmental (Cohen, 1989) aspects of creativity. Mini-c is defined as the novel and personally meaningful interpretation of experiences, actions, and events (Beghetto \& Kaufman, 2007), and similar to Niu and Sternberg's (2006) notion of "individual creativity," as well as developmental conceptions of creativity (Beghetto \& Plucker, 2006; Cohen, 1989; Sawyer et al., 2003; Vygotsky, 1967/2004). So in language learning, min-C emphasize on the dynamic, interpretive process of constructing personal knowledge and understanding within a particular sociocultural context. This is more practical and can be fostered in developing learners' selfesteem, taking risks and challenges, being playful with language and offering new perspectives.

Second, understanding thinking skills has expanded, moving from developing personal cognitive capacity to enhancing social ability and engagement, including collaboration. This new understanding of thinking skills also introduces new approaches to researching thinking skills, for example, in this special issue, we see different methodological approaches, such as case study, narrative, mixed method and so on. The variety of research methodology does not only offer different lenses to study thinking skills, but also demonstrates the openness of researchers in this field, and the robustness and originality of research design.

Third, it is almost certain that future directions of research in teaching thinking skills need to start from teacher education and development. As starting point is to research teacher cognition. As Li (this volume) pointed out the lack of research in teacher cognition about thinking skills. More research needs to carried out to understand how teachers conceptualise thinking skills, how they promote a particular thinking skill, what tasks / activity is appropriate in developing 'thinking space' (Li, 2011) and how to address the factors hindering their implementation of thinking skills. Another area worth for future investigation is the link between metacognition and academic success. Question such as 'how do successful language learners differ in metacognitive knowledge and strategies from less successful language learners' is an important one not only to develop self-regulated and autonomous learners, 
but enabling students to become more strategic and more purposeful in learning. A third area, which is highly worth investigating is creativity in language learning and the benefit of creative thinking in language learning. Apart from encouraging playfulness in language (Carter, 2004), methods, materials and tasks are needed to develop independent, unconventional and curious learners, who are willing to take risks, and being flexible and collaborative. There is certainly a need to bring the links between our theoretical understanding of creativity and everyday practice at personal and individual level. In the field of thinking and creativity, there are currently a number of differing conceptions and meanings. Although no consensus as to what creativity is and how best to encourage it (Craft, 2005), it has been recognized as an important skill. In linking creativity and thinking, Sotto (1994) suggested that an understanding of creativity is the key to 'learning all learning' (p.200). A final area which deserves more attention is the role of technology in developing thinking skills. As suggested earlier, various technological tools and environments have been adopted in fostering thinking skills and there is a trend in integrating technology in all aspects of learning. We are now educating net generation who are constantly engaged with mobile learning. Clearly, there is a need for more research on the role of technology in enhancing creativity and thinking skills, from both a teaching and learning perspective and that of assessment.

\section{References}

Atkinson, D. (1997). A critical approach to critical thinking in TESOL. TESOL Quarterly, 31(1), 71 - 94. Craft, A. (2005). Creativity in Schools: Tensions and dilemmas. London: Routledge.

Beghetto, R. A. (2008). Prospective teachers' beliefs about imaginative thinking in K-12 schooling. Thinking Skills and Creativity, 3, 134-142.

Beghetto, R. A., \& Kaufman, J. C. (2007). Toward a broader conception of creativity: A case for mini-c creativity. Psychology of Aesthetics, Creativity, and the Arts, 1, 73-79.

Beghetto, R. A., \& Plucker, J. A. (2006). The relationship among schooling, learning, and creativity: "All roads lead to creativity" or "You can't get there from here?" In J. C. Kaufman \& J. Bear (Eds.). Creativity and Reason in Cognitive Development (pp. 316-332). Cambridge, NY: Cambridge University Press.

Carter, R. (2004). Language and Creativity. The Art of Common Talk. Routledge.

Cohen, L. M. (1989). A continuum of adaptive creative behaviors. Creativity Research Journal, 2, 169183.

Cottrell, S. (2005). Critical thinking skills. London, UK: Pallgrave McMillan.

Craft, A. (2000), Creativity Across the Primary Curriculum. London: Routledge Fisher, A. (2001). Critical thinking: An introduction. Cambridge, UK: Cambridge University Press.

Craft, A. (2005) Creativity in schools: tensions and dilemmas. Abingdon: Routledge.

Dewey, J. (1909). How We Think. Boston, MA: D.C. Heath and Co.

Fisher, A (2011) Critical Thinking: An Introduction (2nd edition). Cambridge: Cambridge University Press

Fisher, A. \& Scriven, M. (1997). Critical Thinking: Its Definition and Assessment. University of East Anglia,Centre for Research in Critical Thinking

Flavell, J. H. (1979). Meta-cognition and cognitive monitoring: A new area of cognitive developmental 
inquiry. American Psychologist, 34, 906-911.

Higgins, S.E. (2014). Critical thinking for a 21st century education: A cyber-tooth curriculum? Prospects, 44(4), 559-574.

Kaufman, J. C. \& Beghetto, R. A. (2009). Beyond Big and Little: The Four C Model of Creativity. Review of General Psychology, 13 (1), 1-12.

Kletzien, S. B. (1991). Strategy use by good and poor comprehenders reading expository text of differing levels. Reading Research Quarterly, 26 (1), 67-86.

Li, L. (2011). Obstacles and opportunities for developing thinking through interaction in language classrooms. Thinking Skills and Creativity, 6(3), 146-158.

Li, L. \& Wegerif, R. (2014). What does it mean to teach thinking in China? Challenging and developing notions of 'Confucian education'. Thinking Skills and Creativity, 11, 22-32

Lipman, M (2003). Think in Education (2 ${ }^{\text {nd }}$ edition). Cambridge: Cambridge University Press.

Liu, P. Y. \& Li, L. (2015). An overview of metacognitive awareness and L2 reading strategies. In R. Wegerif, L. Li \& J. Kaufman (Eds) The Routledge International Handbook of Research on Teaching Thinking (pp. 266-279). New York: Routledge

Lockley, T. (2013). International history as CLIL: reflection, critical thinking and making meaning of the world. Asian EFL Journal. 15 (4), 330-338.

MacDonald, S. (2005) A Century of Arts and Design Education. Cambridge: Lutterworth Press.

Marin, L. M., and Halpern, D. F. (2011). Pedagogy for developing critical thinking in adolescents: Explicit instruction produces greatest gains. Thinking Skills and Creativity, 6(1), 1-13.

Mok, J. (2009). From Policies to Realities: Developing Students' Critical Thinking in Hong Kong Secondary School English Writing Class, RELC Journal, 40 (3), 262-279.

Mo'nos, K. (2005). A study of the English reading strategies of Hungarian university students with implications for reading instruction in an academic context. Malaysian Journal of ELT Research. Retrieved from http://www.melta.org.my/Doc/MonosK_Eng_reading_strategies.pdf

Niu, W., \& Sternberg, R. J. (2006). The philosophical roots of western and eastern conceptions of creativity. Journal of Theoretical and Philosophical Psychology, 26, 18-38.

Runco, M. A. (1996). Personal creativity: Definition and developmental issues. New Directions for Child Development, 72, 3-30.

Sawyer, R. K., John-Steiner, V., Moran, S., Sternberg, R., Feldman, D. H., Csikszentmihalyi, M., Nakamura, J. (2003). Creativity and development. New York: Oxford University Press.

Sheorey, R., \& Mokhtari, K. (2001). Differences in the metacognitive awareness of reading strategies among native and non-native readers. System, 29, 431-449.

Sotto, E. (1994). When teaching becomes learning. London: Cassel Wellington Publishing House.

Stapleton, P. (2001). Assessing critical thinking in the writing of Japanese university students $\square$ Insights about assumptions and content familiarity. Written Communication, 18(4), 506-548. 
Voogt, J., Erstad, O., Dede, C., \& Mishra, P. (2013). Challenges to learning and schooling in the digital networked world of the 21st century. Journal of Computer Assisted Learning 29, 403-413

Vygotsky, L. (1978). Mind in Society. Cambridge, MA: Harvard University Press.

Vygotsky, L. S. (2004). Imagination and creativity in childhood. (M. E. Sharpe, Inc., Trans.). Journal of Russian and East European Psychology, 42, 7-97. (Original work published 1967).

Wang Y. \& Henderson. F. (2014). Teaching Content Through Moodle to Facilitate Students' Critical Thinking in Academic Reading. The Asian EFL Journal Quarterly, 16 (3)

Wu, W-C. V., Marek, M.W., \& Chen, N-S. (2013). Assessing cultural awareness and linguistic competency of EFL learners in a CMC-based active learning content. System, 4(3), 515-528.

Wegerif, R. (2006). A dialogic understanding of the relationship between. CSCL and teaching thinking skills. International Journal of Computer Supported Collaborative Learning, 1(1), 143-157.

Wegerif, R., Li, L. and Kaufman, J.C. (2015). The Routledge International Handbook of Research on Teaching Thinking. New York: Routledge.

Yang, Y. C., Chuang, Y., Li, L., \& Tseng, S. (2013). A blended learning environment for individualized English listening and speaking integrating critical thinking. Computers and Education, 63, 285-305.

Yayli, D. (2010). A think-aloud study: Cognitive and meta-cognitive reading strategies of EFL department students. Egitim Arastirmalari - Eurasian Journal of Educational Research, 38, 234-251.

Zhang, L. J. (2001). Awareness in reading: EFL students' meta-cognitive knowledge of reading strategies in an acquisition-poor environment. Journal of Language Awareness, 10, 268-288.

Zhang, L. J. (2010). A dynamic metacognitive systems account of Chinese university students' knowledge about EFL reading, TESOL Quarterly, 44, 320-353.

Zhang, D. L., \& Goh, C. M. (2006). Strategy knowledge and perceived strategy use: Singaporean students' awareness of listening and speaking strategies. Language Awareness, 15 (3), 198-219. (2), $320-356$.

Zhou, J., Jiang. Y. \& Yao, Y. (2015). The Investigation on Critical Thinking Ability in EFL Reading Class. English Language Teaching, 8 (1), 83-94. 